\title{
Aluminum Detoxification by Humic Substance Extracted from Compost of Organic Wastes
}

\author{
Sugeng Winarso ${ }^{1}$, Eko Handayanto ${ }^{2}$ and Abdullah Taufiq ${ }^{3}$ \\ Received 16 November 2009 / accepted 31 December 2009
}

\begin{abstract}
Aluminum Detoxification by Humic Substance Extracted from Compost of Organic Wastes (S Winarso, E Handayanto and A Taufiq): Humic substance could control the activity of metal as well as exchangeable aluminum $\left(\mathrm{Al}_{\text {exch }}\right)$ on acid soil. The humic substance extracted from compost of agricultural waste is rarely conducted. The objective of research was to evaluate the effect of humic substance concentration and sources to $\mathrm{pH}$ and $\mathrm{Al}$ suspension. The research had been conducted in the Soil Laboratory of Agricultural Faculty of Jember University from April to July 2009. The humic substance used in these researches was extracted from compost of rice straw (RS), soybean straw (SS), cassava starch solid waste (CSSW), and empty bunch of oil palm tree (EBOPT). The humic substance concentration treatments were $0,10,20,30,40,50,75,100,150,200,250$, and $300 \mathrm{ppm}$. Result of the analysis showed that characteristic of humic substance was difference depending on the source material used. The humic substance extracted from SS contains total base cations (K, Na, Ca, Mg) higher (1.17\%) compared with CSSW (1.07\%), OPT $(0.87 \%)$, and RS $(0.69 \%)$. While the humic substances extracted from RS contain total organic acid (Acetic, Fumeric, Cetoglutamic, Sucsinic, Propionic, Butiric, Ocsalic, and Citric Acid) higher (157 ppm) compared with EBOPT (129 ppm), SS (115\%), and CSSW (108\%). Among these organic acids, acetic acid was highest concentration (> $34.51 \%$ of total acid). The addition of humic substance increased $\mathrm{pH}$ and decreased aluminum concentration of the suspension. The higher $\mathrm{pH}$ increment and $\mathrm{Al}$ concentration reduction took place in the suspension treated with humic substance from SS compost. The correlation between decreasing Al concentration with humic substance concentration which explained chelation was higher $(\mathrm{r}=0.97)$ than decreasing $\mathrm{Al}$ concentration with increasing $\mathrm{pH}$ which explained precipitation $(r=0.93)$. Based on these research results, it can be concluded that humic substance extracted from agricultural waste have a good prospect as a soil ameliorant to increase soil $\mathrm{pH}$, detoxify soil aluminum, and increase soil $\mathrm{P}$ availability on acid soil.
\end{abstract}

Keywords: Aluminum, chelate, compost, humic substance

\section{INTRODUCTION}

Previous researches showed that humic substance affect soil characteristic, water, and environment. The role of humic substance in the soil that affect or control the metal activities and other pollutant (like pesticide) were studied by previous researchers, for example $\mathrm{Cu}$ (Karlsson et al. 2008), Uranium (Singhal et al. 2006), $\mathrm{Hg}$ and $\mathrm{Pb}$ (CruzGuzma et al. 2003), and pesticide (Li et al. 2003).

Aluminum $(\mathrm{Al})$ content in the soil is very high, but the solubility is very low. The Al solubility will increase as the soil acidity increase (Lindsay 1979). Aluminum concentration on Ultisol Kentrong Banten was more that $6.02 \mathrm{cmol} \mathrm{kg}^{-1}$ (Winarso 2009), and this concentration could be toxic to plant. High Al concentration not only has a negative effect on plant root growth, but also potentially retard nutrient absorbtion, like Mg (Sverdrup and Warfvinge 1993).

Humic substance decreases $\mathrm{Al}$ concentration in acid soil throught chelation prosess. Winarso et al. (2009) reported that humic substance extracted from rice straw compost decreased exchangeable $\mathrm{Al}$ on Ultisol through precipitation due to soil $\mathrm{pH}$ increased

\footnotetext{
${ }^{1}$ Faculty of Agriculture, University of Jember (UNEJ). Jl. Kalimantan 33 Jember - Post Code 68121; e-mail:sgwinarso@yahoo.co.id

${ }^{2}$ Faculty of Agriculture, University of Brawijaya (UB); e-mail: ekohanda@telkom.net

${ }^{3}$ Balitkabi Malang; e-mail: ofic_rilet@yahoo.com

J Trop Soils, Vol. 15, No. 1, 2010: 19-24

ISSN 0852-257X
} 
and/or through chelation by functional group, especially carboxilate.

The objective of the research was to evaluate the effect of humic substance addition, that was extracted from compost of rice straw, soybean straw, cassava starch solid waste and oil palm tree, to $\mathrm{pH}$ and $\mathrm{Al}$ suspension.

\section{MATERIALS AND METHODS}

\section{Extraction of Humic Substance}

The humic substance used in the research was extracted from the compost of rice straw (RS), soybean straw (SS), cassava starch solid waste (CSSW) and empty bunch of oil palm tree (EBOPT). Composting these organic materials and extracting the humic substance were conducted without any chemical addition that might affect humic substance characteristic. Aerobic composting was conducted by controling aeration and water content condition. The humic substance was extracted mechanically by pressing the composted material. Chemical extraction by addition of $\mathrm{NaOH}$ solution did non execute to prevent out side material to become part of humic substance compound. Characteristic of humic substance was based on organic acids analysis (acetic acid, citric acid, oxsalic acid, propionic acid, butiric acid, sucsinic acid, fumiric acid, and cetoglutamic acid ) using HPLC at Laboratory of PT Bogor Agro Lestari; $\mathrm{pH}$ (pH meter Jenway); C-organic (Walkey and Black method); N (Kjeldahl method); $\mathrm{P}, \mathrm{K}, \mathrm{Na}, \mathrm{Ca}, \mathrm{Mg}, \mathrm{Fe}, \mathrm{Cu}, \mathrm{Zn}$, and $\mathrm{Mn}$ (wet ashing with $\mathrm{HNO}_{3}+\mathrm{HClO}_{4}$, measured using Spectrophotometer for $\mathrm{P}$ and Atomic Absorption Spectrophotometer for the other ones).

\section{Experiment Setup}

The research consisted of two experiments. The first experiment aimed to evaluate the effect of addition of humic substance extracted from some agricultural wastes on suspension $\mathrm{pH}$. The experiment was conducted at Soil Laboratory of Agricultural Faculty of Jember University on April to July 2009. The humic substance concentration used were $0,10,20,30,40,50,75,100,150,200,250$, and $300 \mathrm{ppm}$ with total suspension volume of 100 $\mathrm{ml}$. The suspension was shaken two hours a day during a week in ambient temperature, and then the suspension $\mathrm{pH}$ was measured.
The second experiment aimed to evaluate the effect of addition of humic substance extracted from some agricultural wastes on $\mathrm{pH}$ and $\mathrm{Al}$ suspension. The experiment was conducted in the same place and time as the first one. The humic substance concentration used were $0,50,75,100,150,200,250$, and $300 \mathrm{ppm}$. Aluminum used to express metal come from $\mathrm{AlCl}_{3}$ pure analysis (pa) with concentration of 2 $\mathrm{m} M$. The suspension was shaken two hours a day during a week in ambient temperature, and then the suspension $\mathrm{pH}$ was measured directly. Aluminum was measured based on titration method from $N \mathrm{KCl}$ extraction.

\section{Data Analysis}

All of humic substance concentration treatments were replicated 3 times and the value were average. Regression equations and pattern of two variables relationships were analyzed simplify with Microsoft Office Excel 2007.

\section{RESULTS AND DISCUSSION}

\section{Characteristics of Humic Substance}

Result of humic substance analysis indicated that humic substance extracted from compost of RS, SS, CSSW, and EBOPT showed different chemical characteristic (Table 1). The humic substance extracted from SS contains total base cations (K, Na, $\mathrm{Ca}, \mathrm{Mg}$ ) higher $(1.17 \%)$ compared with CSSW $(1.07 \%)$, OPT $(0.87 \%)$, and RS $(0.69 \%)$. While the humic substances extracted from RS contain total organic acid (Acetic, Fumeric, Cetoglutamic, Sucsinic, Propionic, Butiric, Ocsalic, and Citric Acid) higher (157 ppm) compared with EBOPT (129 ppm), SS (115\%), and CSSW (108\%). Among these organic acids, concentration of acetic acid $\left(\mathrm{CH}_{3} \mathrm{COOH}\right.$, alifatic and single carboxilate) was the highest i.e. $34.51 \%$ of total acid for humic substance from SS and $>40 \%$ of total acid for humic substance from RS, CSSW and EBOPT.

Acetic acid, Fumiric acid, Cetoglutamic acid, Sucsinic acid, Propionic acid, Butiric acid, Oxalic acid, and Citric Acid are organic acid that contain double as well as single chain carboxylic functional group (-COOH) (Hart et al. 2003). If this functional group dissosiates it's proton (ion $\mathrm{H}^{+}$), it becomes negative (anion compound) and it can chelate $\mathrm{Al}$ in the soil suspension (Essington and Anderson 2008). 
Table 1. Characteristic of humic substance extracted from compost of some agricultural wastes.

\begin{tabular}{|c|c|c|c|c|c|}
\hline \multirow{2}{*}{ Variable } & \multirow{2}{*}{ Unit } & \multicolumn{4}{|c|}{ Hu mic substance from compost of } \\
\hline & & $\begin{array}{l}\text { Empty bunch of } \\
\text { oil palm tree }\end{array}$ & $\begin{array}{l}\text { Cassava starch } \\
\text { solid waste }\end{array}$ & $\begin{array}{l}\text { Rice } \\
\text { straw }\end{array}$ & $\begin{array}{c}\text { Soybean } \\
\text { straw }\end{array}$ \\
\hline Acetic acid & $\mathrm{ppm}$ & 56 & 46 & 94 & 39 \\
\hline Citric acid & ppm & 18 & 10 & 12 & 16 \\
\hline Oxalic acid & ppm & 20 & 16 & 17 & 22 \\
\hline Propionic acid & ppm & 2 & 4 & 6 & 9 \\
\hline Butyric acid & ppm & 1 & $\mathrm{tt}$ & 1 & $\mathrm{tt}$ \\
\hline Sucsinic acid & ppm & 21 & 11 & 16 & 18 \\
\hline Fumiric acid & ppm & 9 & 21 & 11 & 8 \\
\hline Cetoglutamic acid & $\mathrm{ppm}$ & 2 & $\mathrm{tt}$ & $\mathrm{tt}$ & 1 \\
\hline $\mathrm{pH}$ & & 8.60 & 4.60 & 7.60 & 8.70 \\
\hline C-organic & $\%$ & 0.32 & 1.69 & 0.17 & 0.17 \\
\hline $\mathrm{C} / \mathrm{N}$ ratio & & 23.2 & 30.2 & 15.0 & 6.8 \\
\hline $\mathrm{N}$ & $\%$ & 0.01 & 0.06 & 0.01 & 0.03 \\
\hline $\mathrm{P}_{2} \mathrm{O}_{5}$ & $\%$ & 0.02 & 0.02 & 0.01 & 0.01 \\
\hline $\mathrm{K}_{2} \mathrm{O}$ & $\%$ & 0.11 & 0.06 & 0.06 & 0.10 \\
\hline $\mathrm{NaO}$ & $\%$ & 0.01 & 0.02 & 0.01 & 0.02 \\
\hline $\mathrm{CaO}$ & $\%$ & 0.62 & 0.68 & 0.49 & 0.92 \\
\hline $\mathrm{MgO}$ & $\%$ & 0.13 & 0.31 & 0.13 & 0.13 \\
\hline $\mathrm{Fe}$ & ppm & 11.0 & 68.3 & 1.3 & 6.0 \\
\hline $\mathrm{Cu}$ & ppm & $\mathrm{tt}$ & $\mathrm{tt}$ & $\mathrm{tt}$ & $\mathrm{tt}$ \\
\hline $\mathrm{Zn}$ & ppm & 0.75 & 9.00 & 2.38 & 3.50 \\
\hline $\mathrm{Mn}$ & ppm & 298 & 295 & 679 & 834 \\
\hline Mo & ppm & 163 & 101 & 71 & 121 \\
\hline B & ppm & 305 & 148 & 250 & 314 \\
\hline
\end{tabular}

The highest acetic acid concentration (carbon alifatic chain) (Table 1) indicates that decomposition process does not complete yet. Ait Baddi et al. (2003) reported that aromatic degree of humic substance extracted from compost of olive mill waste increased with increasing period of decomposition or the compost maturity. After 12 months decomposition, humic acid from this humic substance contains high aromatic structure and the reverse for alifatic structure. Winarso (2009) reported that humic substance from rice straw composted during a year contains sucsinic acid (aromatic and dicarboxcilate) higher $(20.9 \%)$ compared with other organic acid.

The existing of organic acids containing functional group was in line with the hyphotesis from Stevenson (1982) and Buffle et al. (1977) about the model of humic acid and fulvic acid structure that are fraction of humic compound. Until the moment, there is no aggrement about humic acid and fulvic acid structures. Beside that, procedure of humic substance fractionation to humic acid, fulvic acid and humin; extraction and purification recommended by "The International Humic Substances Society" are based on chemically dillution process in the acid-base system.

The $\mathrm{pH}$ of humic substance originated from compost of many agricultural wastes varied from $\mathrm{pH}$ 7.6 to 8.7, except from CSSW which pH value of 4.6 (Table 1). High $\mathrm{pH}$ seems correlated with high $\mathrm{Ca}$, $\mathrm{Mg}, \mathrm{K}$ and $\mathrm{Na}$ content (Table 1 ). Among the cation, $\mathrm{Ca}$ content was dominant $(>70 \%$ of the total base cation) followed by $\mathrm{Mg}, \mathrm{K}$ and $\mathrm{Na}$. In case of $\mathrm{Ca}$ and $\mathrm{Mg}$ content, humic substance originated from compost of many agricultural wastes contains $\mathrm{Ca}$ and $\mathrm{Mg}$ ten times higher compared with K-Humat Plus 26\% (produced comercially by Omnia Australia). It also contains other macro and micro nutrient $(\mathrm{N}, \mathrm{P}$, $\mathrm{Fe}, \mathrm{Zn}, \mathrm{Mn}, \mathrm{Mo}$, and B).

The composition of basic cation in the humic substance originated from compost of many 
agricultural wastes was better than the comercial one. The basic cation in the comercial humic substance dominated by $\mathrm{Na}$ rather than $\mathrm{K}, \mathrm{Ca}$, and $\mathrm{Mg}$ (Cerdan et al. 2007). Na is non esential element for plant, and on high concentration in the soil it can destroy plant root due to plasmolysis. Beside that, it also can disperse soil coloids and therefore soil become sensitive to erosion and compaction.

Based on these characteristic, the humic substance originated from compost of many agricultural wastes might have multiple function: it could be as fertilizer, acid soil ameliorant, and for amelioration of soil contaminated by metal around the mining area.

\section{Aluminum Detoxification by Humic Substance}

Addition of humic substance originated from compost of RS, SS and EBOPT increased $\mathrm{pH}$ suspension as humic substance concentration increased (Figure 1). Higher $\mathrm{pH}$ increament took place at concentration below $50 \mathrm{ppm}$, while $\mathrm{pH}$ level at concentration above $50 \mathrm{ppm}$ to $350 \mathrm{ppm}$ was relativly constant ( $\mathrm{pH}$ about 8.5). Addition of humic substance originated from compost of CSSW could not change suspension $\mathrm{pH}$, since it had low $\mathrm{pH}(\mathrm{pH}=4.6)$. Humic substance originated from compost of SS had higher $\mathrm{pH}$ (8.7) and therefore increased $\mathrm{pH}$ higher than the other one. It means that humic substance originated from compost of SS, RS and EBOPT can be used as acid soil amandement like Ultisol and Oxisol.

Addition of humic substance originated from SS at concentration of $200 \mathrm{ppm}$ caused initial Al concentration in the suspension as much as $2 \mathrm{mM}$ became undetactable (value $=0$ ) (Figure 2). Significant decreased in $\mathrm{Al}$ concentration also took placed by addition of humic substance originated from the other sources. Aluminum concentration reduction was caused by precipitation as $\mathrm{Al}(\mathrm{OH})_{3}$ due to $\mathrm{pH}$ increament, and/or chelation (linkage by more than one deprotonized functional group, especially carboxilate and some phenolate or other ones). This phenomenon indicated that humic substance originated from compost of agricultural wastes is highly potential to netralize Al.

The correlation value between extracted $\mathrm{Al}$ with humic substance concentration indicated that reduction in $\mathrm{Al}$ concentration was caused by chelation by functional groups of humic substance and then precipitated due to $\mathrm{pH}$ increment (Figures 2 and 3). Among the correlation values, correlation value between concentration of humic substance from compost of SS with extracted $\mathrm{Al}$ was higher $(\mathrm{r}=0.97)$. Relationship between humic substance concentration and extracted $\mathrm{Al}$ was quadratic, and equation with higher determination coefficient was from RS, i.e. $\mathrm{y}_{\mathrm{p}}=7 \mathrm{E}-06 \mathrm{X}^{2}-0.004 \mathrm{X}+0.808 ; \mathrm{R}^{2}=0,947$. Skyllberg (1999) stated that complex Al-organic matter valid at $\mathrm{pH}<4.2$ and in the unsaturated $\mathrm{Al}(\mathrm{OH})_{3}$ solution.

Addition of $2 \mathrm{mM} \mathrm{AlCl}$ in the water decreased solution $\mathrm{pH}$ to nearly 4 . Addition and humic substance concentration increment increased $\mathrm{pH}$, except in the treatment with addition of humic substance originated from compost of SS (Figure 3). This result was in line with the previous research without any $\mathrm{Al}$ addition Al (Figure 1). Figure 3 also showed relationship between $\mathrm{pH}$ with $\mathrm{Al}$ extracted with $\mathrm{KCl}$

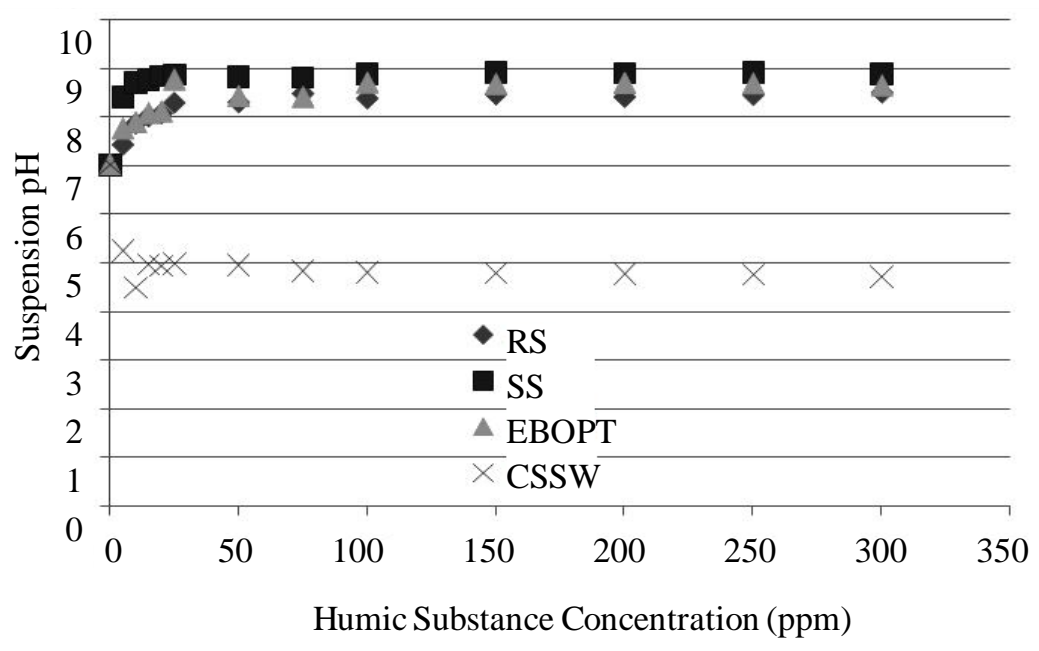

Figure 1. Effect of humic substance concentration to suspension $\mathrm{pH}$. 


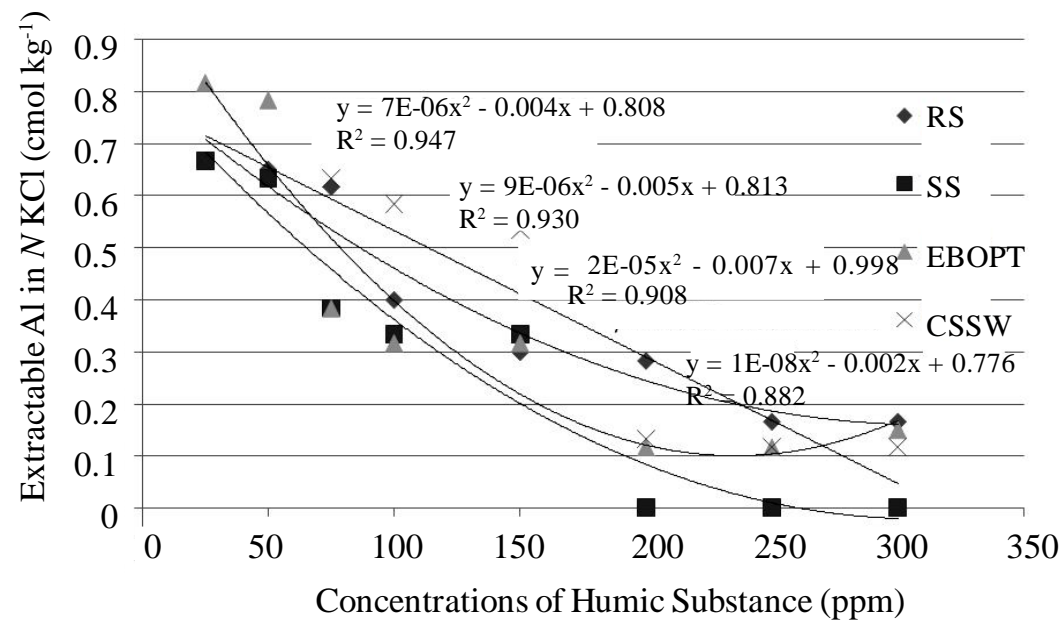

Figure 2. Relationship between concentrations of humic substance originated from compost of some agricultural wastes with extractable $\mathrm{Al}$ in $N \mathrm{KCl}$ in the suspension containing $2 \mathrm{mM} \mathrm{AlCl}$.

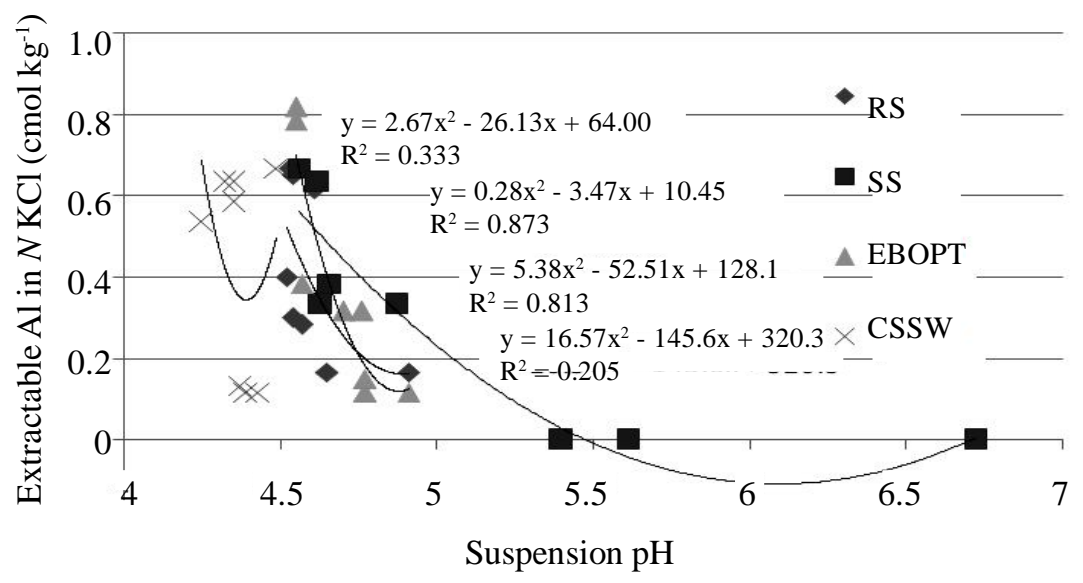

Figure 3. Relationship between $\mathrm{pH}$ with extractable $\mathrm{Al}$ in $N \mathrm{KCl}$ in the suspension containing humic substance originated from compost of some agricultural wastes and $2 \mathrm{mM} \mathrm{AlCl}$.

from suspension containing humic substance originated from some compost sources and $2 \mathrm{mM}$ $\mathrm{AlCl}_{3}$. The equation between these two variables was quadratic, but had lower coefficient determination $\left(\mathrm{R}^{2}\right)$ compared with $\mathrm{R}^{2}$ between humic substance and $\mathrm{Al}$ (Figure 2). The highest correlation value took place between humic substance originated from SS compost $(r=0.93)$, followed by humic substance originated from EBOPT compost $(r=0.90)$, $R S$ compost $(r=$ $0.58)$ and CSSW compost $(r=0.45)$.

Based on these explanations, correlation value, and relationship between $\mathrm{Al}$ and humic substance concentration indicated that reduction of $\mathrm{Al}$ concentration was primarily due to chelation by functional groups of humic substance rather than by precipitation due to $\mathrm{pH}$ increment. This close relationship between humic substance concentrations with $\mathrm{Al}$ measured at $\mathrm{pH}$ in the range of 4 to 5.5. Winarso (2009) showed that Al detoxification on Ultisol ( $\mathrm{Al}_{\text {-exch }}$ undetected) by humic substance and $\mathrm{CaCO}_{3}$ effective on $\mathrm{pH}$ at about 5.5.

The results indicated that $\mathrm{Al}$ chelation and precipitation by humic substance originated from some agricultural wastes compost can be used to control metal element on land metal-contaminated. So that, it needs further research to know effective concentration on certain $\mathrm{pH}$ and certain metal element, since low humic substance concentration will promote metal mobilization especially in the water canal. 


\section{CONCLUSIONS}

Characteristic of humic substance was difference depending on the source material used. The humic substance extracted from soybean straw contains total basic cations (K, $\mathrm{Na}, \mathrm{Ca}, \mathrm{Mg}$ ) higher (1.17\%) than that extracted from cassava starch solid waste (1.07\%), empty bunch of oil palm tree $(0.87 \%)$, and rice straw $(0.69 \%)$. Humic substance extracted from rice straw contains total organic acid (Acetic acid, Fumeric acid, Cetoglutamic acid, Sucsinic acid, Propionic acid, Butiric acid, Oxalic acid, and Citric acid) higher (157 ppm) compared with the other. Among these organic acids, acetic acid was the highest concentration ( $>40 \%$ of total acid) except in the humic substance from rice straw compost (34.51\%).

The addition of the humic substance decreased aluminum concentration of the suspension. Higher reduction of $\mathrm{Al}$ took place in the suspension treated with 200 ppm humic substance from soybean straw compost. $\mathrm{Al}$ detoxification by humic substance in various pHs below 5.5 levels primarily due to chelation rather than precipitation.

Further research to identify optimum concentration of humic substance to detoxify metal element in the soil and phosphorous desorption in acid soil.

\section{ACKNOWLEDGMENT}

Thanks a lot to Muhhamad Ilham on his help in conducting this research. This paper is part of applied research result founded by KMNRT 2009.

\section{REFERENCES}

Ait Baddi G, M Hafidi, V Gilard and JC Revel. 2003. Characterization of humic acids produced during composting of olive mill wastes: elemental and spectroscopic analyses (FTIR and 13C-NMR). Agronomie 23: 661-666.
Buffle J, FL Greter and W Haerdi. 1977. Measurements of complexation properties of humic and fulvic acids in natural waters with lead and copper ion-selective electrodes. Anal Chem Acta 49: 216-222.

Cerdan M, S Alcaniz, M Juarez, JD Jorda and D Bermudez. 2007. Kinetic Behavior of Fe (o,o-EDDHA)-Humic Substance Mixtures in Several Soil Components and in Calcareous Soils. J Agric Food Chem 55: 91599169.

Cruz-Guzma M, R Celis, MC Hermosýn, P Leone, M Negre and J Cornejo. 2003. Sorption-Desorption of Lead (II) and Mercury (II) by Model Associations of Soil Colloids. Soil Sci Soc Am J 67: 1378-1387.

Essington ME and RM Anderson. 2008. Competitive Adsorption of 2-Ketogluconate and Inorganic Ligands onto Gibbsite and Kaolinite. Soil Sci Soc Am J 72: 595-604.

Hart H, LE Craine and DJ Hart. 2003. Organic Chemistry. A Short Course. Houghton Mifflin Company: 305344.

Karlsson T, K Elgh-Dalgren and U Skyllberg. 2008. Modeling Copper(II) Complexation in a Peat Soil Based on Spectroscopic Structural Information. Soil Sci Soc Am J 72: 1286-1291.

Li H, G Sheng, BJ Teppen, CT Johnston and SA Boyd. 2003. Sorption and Desorption of Pesticides by Clay Minerals and Humic Acid-Clay Complexes. Soil Sci Soc Am J 67: 122-131.

Lindsay WL. 1979. Chemical Equilibria in Soils. A WileyInterscience Publication. Toronto.

Singhal RK, AG Hegde and ML Joshi. 2006. The role of aquatic humic substances on speciation of different elements in surface and subsurface water around trombay. BARC Newsletter. Issue 264: 17-25.

Stevenson FJ. 1982. Humus Chemistry, Genesis, Composition, Reaction. A Wiley-Interscience Pub. John Willey and Sons. Toronto.

Winarso S. 2009. Detoksitas Alumunium dan Desorpsi Fosfat pada Ultisol dengan Menggunakan Senyawa Humik dan Bakteri Pelarut Fosfat. Disertasi. Program Pascasarjana Fakultas Pertanian Universitas Brawijaya Malang. 183p.

Winarso S, E Handayanto, Syekhfani, and D Sulistyanto. 2009. Pengaruh Kombinasi Senyawa Humik dan $\mathrm{CaCO}_{3}$ terhadap Alumunium dan Fosfat Typic Paleudult Kentrong Banten. J Tanah Trop 14 (2): 8995. (In Indonesian). 